\title{
Research on the influence of China's outward foreign direct investment on technological progress of equipment manufacturing industry
}

\author{
Chen Shaogui
}

Department of Economics, Central University of Finance and Economics, China

Received: 30 Sept 2020; Received in revised form: 27 Nov 2020; Accepted: 01 Dec 2020; Available online: 13 Dec 2020

(C2020 The Author(s). Published by Infogain Publication. This is an open access article under the CC BY license

(https://creativecommons.org/licenses/by/4.0/).

\begin{abstract}
Based on the panel data of 30 provinces in China (excluding Tibet) from 2003 to 2017, this paper constructs the input-output index system, calculates the changes of total factor productivity of equipment manufacturing industry in 30 provinces by using DEA Malmquist analysis model, and further analyzes the impact of China's outward foreign direct investment on the technological progress of domestic equipment manufacturing industry by using the method of Dynamic Panel System GMM influence. The results show that: Although China's outward foreign direct investment and technological progress of equipment manufacturing industry present a significant positive " $U$ " shape, that is, at the initial stage of foreign investment, the increase of foreign direct investment will reduce the efficiency of technological progress of equipment manufacturing industry, when the outward direct investment reaches a certain scale, that is, when the growth rate of foreign direct investment exceeds a certain threshold, foreign direct investment will significantly promote equipment manufacturing technology progress. From the regional level, the threshold value of the central region is the smallest, which indicates that the scale of foreign investment needed to promote the technological progress of equipment manufacturing industry is relatively small. Finally, this paper puts forward the countermeasures and suggestions on how to use foreign direct investment to improve the technical progress of China's equipment manufacturing industry and promote the high-quality development of equipment manufacturing industry.
\end{abstract}

Keywords-outward foreign direct investment; equipment manufacturing industry; reverse spillover effect; technological progress

\section{INTRODUCTION}

With the development of economic globalization, the change of international division of labor has a profound impact on the global manufacturing division pattern. For a long time, manufacturing plays an important part in China's economic development, is the leading industry and pillar industry of the national economy. Equipment manufacturing industry is the "mother machine" of other industrial industries, which is an important manufacturing industry. The development of equipment manufacturing industry is the precondition for realizing the all-round modernization of industry. At present, the domestic equipment manufacturing industry is in the middle and lower reaches of the global value chain due to its low technology content and weak international competitiveness. At the moment, the trend of antiISSN: 2456-7620

https://dx.doi.org/10.22161/ijels.56.40 globalization is surging in Europe and the United States. The "Reindustrialization" strategy of western developed countries has an important impact on the pattern of global manufacturing division of labor, and has a "crowding out effect" on the division of labor of manufacturing industry in underdeveloped countries. In addition, Southeast Asia and other developing countries are deeply involved in the international division of labor with labor cost advantage, and China's equipment manufacturing industry is facing a severe challenge of "two-way extrusion". Therefore, it is urgent to strengthen the scientific and technological innovation ability of China's equipment manufacturing industry, promote its technological progress and improve its international competitiveness.

With China's entry into a new round of reform and opening up, China's outward foreign investment has 
Nov-Dec 2020 / Available online: https://ijels.com/

increased rapidly. Since the relevant departments of China officially released the annual statistical data in 2003, China's global foreign direct investment flow ranked the top three for seven consecutive years, contributing more and more to the world economy. Since 2015, China's outward foreign direct investment (OFDI) has exceeded the actual utilization of foreign direct investment (FDI) for four consecutive years, and China has become a net capital exporter. Foreign direct investment (FDI) has become the booster of China's high-quality economic development. According to the theory and practice of open economy, such large-scale foreign investment will certainly bring important economic impact to the home country economy, such as: resource allocation effect, industrial upgrading effect, reverse technology spillover effect, technological progress effect, etc., therefore the impact of foreign direct investment on the technological progress of home country's equipment manufacturing industry has attracted many scholars' attention.

\section{LITERATURE REVIEW}

Outward Foreign Direct Investment (OFDI) is generally believed to be the behavior of multinational enterprises to invest in cash, physical objects and intangible assets in order to gain effective control over the operation and management of foreign enterprises. Economic globalization has facilitated the exchange of foreign investment, knowledge and technology among countries. The technological progress of China's equipment manufacturing industry mainly depends on independent research and development, and at the same time, it needs to make full use of the reverse spillover of foreign technology. Reverse technology spillover refers to the process in which the home country of investment obtains technological resources by investing in developed countries or regions where technological resources are concentrated, through cross-border mergers and acquisitions, and through learning, imitating, digesting and absorbing, it drives the technological progress of the home country. For a long time, scholars have paid much attention to the research of reverse technology spillover effect of OFDI. In recent years, with the increase of China's reverse investment in developed countries, many experts and scholars have begun to study the impact of reverse technology spillover effect of OFDI on manufacturing technology progress and global value chain upgrading.

The first is about the technology demand motivation of OFDI. Scholars Zhang Xiaodi et al. (2006) believe that it is the motivation of enterprises in developing countries to obtain and create new competitive advantages through technology seeking OFDI. Yao Limin and Sun Chunyuan
(2007) ${ }^{[1]}$ believe that the main strategic goal of China's current reverse OFDI to developed countries is to promote export trade and acquire advanced science and technology. Zhao Wei and Jiang Dong (2010) believe that when a country carries out foreign direct investment, the fierce international competition environment will promote upstream industries, increase technological research and innovation, and promote technological progress. $\mathrm{Li}$ Dongkun and Deng Min (2016) believe that the fierce international competition environment will force enterprises investing abroad to accelerate technological innovation and improve their competitiveness. Zhang Yu (2018) believes that the improvement of technological innovation ability needs strong support of technology and capital. Strategic asset seeking outward foreign direct investment can obtain more advanced technical resources; efficiency seeking outward foreign direct investment can realize economies of scale and save production costs. These saved funds can be invested in technology innovation and $R \& D$ to help domestic enterprises improve their innovation capability power.

The second is the related research on the reverse technology spillover factors of outward foreign direct investment. Konings (2001) believes that the possibility of R\&D innovation of enterprises carrying out foreign investment and the level of technological progress of enterprises are related to their geographical location and special policies of host countries. Zhao Wei et al. (2006) ${ }^{[2]}$ believe that the more intensive the host country's $R \& D$ resources, the more obvious the OFDI reverse technology spillover effect. Chen Hao and Wu Wen (2016) believe that whether China's outward foreign direct investment can obtain reverse technology spillover is related to the economic development level of the target country. For developed countries, technology spillovers can be obtained, while for transition and developing countries, technology spillovers cannot be obtained, but positive technology output can be generated. Fu Lei and Qiang Yongchang (2014) emphasized that human capital market and product market with free game competition are the premise of OFDI reverse technology spillover.

The third is about the transmission path of technological progress effect of outward foreign direct investment. Most scholars believe that the reverse technology spillover can be realized by acquiring $R \& D$ technology resources, training scientific researchers and feedback R\&D achievements. Zhao Wei et al. (2006) sorted out the mechanism of the relationship between OFDI and China's technological progress, and found that OFDI promoted China's technological progress through R\&D cost sharing, R\&D achievements feedback, reverse technology transfer, and peripheral R\&D stripping. According to Yin Hua et al. 
Nov-Dec 2020 / Available online: https://ijels.com/

(2008), the paths of reverse technology spillover of home country acquisition mainly include: imitation demonstration effect, linkage effect, personnel flow effect and platform effect. Chen Feiqiong et al. (2009) claims that the feedback mechanisms between the foreign investment and technological progress of the enterprise are those of the overseas R\&D, of the benefit, of the localization of subsidiaries and of the public effect of foreign investment. Guo Fei and Huang Yajin (2012) explained the transfer mechanism of OFDI reverse technology spillover by building a triangular circular transmission model of technology interaction, technology transfer and technology absorption. Zou Xi (2017) analyzed the mechanism of reverse technology spillover of technology seeking OFDI from macro and micro levels, from the perspective of forward investment and reverse investment.

The fourth is about the impact of outward foreign direct investment on technological progress of home country. According to the research results, scholars have different views, which can be roughly divided into three categories: the first category believes that OFDI can significantly promote the technological progress of home countries through reverse technology spillover effect. Foreign scholars Kogut et al. (1991) ${ }^{[3]}$, Teece et al. (1992) ${ }^{[4]}$ and Potterie et al. (2001) ${ }^{[5]}$ have empirically proved that there is reverse technology spillover effect in OFDI at the enterprise level and national level, and OFDI has significant spillover effect on domestic productivity. Pradhan et al. (2008) ${ }^{[6]}$ and Herzer (2010) ${ }^{[7]}$ also found that the adverse spillover effect of OFDI exists in any country and industry it invests in, and has national differences. Domestic scholars Liu Mingxia (2010) ${ }^{[8]}$, Guo Fei et al. (2012) ${ }^{[9]}$, Song Yongchao (2015) ${ }^{[10]}$ and Han Yujun (2016) ${ }^{[11]}$ respectively from the industrial level and national level, through empirical analysis, found that China's outward foreign direct investment has a significant reverse technology spillover effect, which has a significant promoting effect on technological progress expressed by total factor productivity. The second is that the reverse technology spillover effect of OFDI has no significant effect on the technology progress of home country. There are mainly foreign scholars such as Bitzer et al. (2008) ${ }^{[12]}$, Lee et al. (2006) ${ }^{[13]}$ and Bitzer et al. (2008) ${ }^{[14]}$. Through empirical research, we find that the impact of OFDI on TFP is negative, and there are obvious differences between countries. Domestic scholar Bai Jie (2009) ${ }^{[15]}$ found that reverse technology spillover of outward foreign direct investment has a positive effect on technological progress, but the improvement is not significant. Xie Yumin et al. (2014) ${ }^{[16]}$ through empirical test, show that: Outward foreign direct investment only has a certain promotion effect on imitation innovation, but has inhibitory effect on overall innovation, independent innovation and secondary innovation. The third category thinks that the reverse technology spillover effect of OFDI can promote the technology progress of home country, but it needs some preconditions. Foreign scholars Bo Rensztein et al. (1998) ${ }^{[17]}$ and Gorg et al. (2004) ${ }^{[18]}$ have shown that there is a certain "threshold effect" in the realization of reverse spillover effect of outward foreign direct investment. Similarly, domestic scholars Zhang Hong, Zhao Jiaying (2008) and Zheng Lei (2012) believe that the technology spillover effect of OFDI also has the "threshold effect". Some experts and scholars use the game equilibrium analysis method to find that there is a threshold value for reverse technology spillover. As long as the "threshold value" is crossed, the enterprise's enthusiasm for outward foreign direct investment will increase significantly. Through empirical research, Chen Yan (2011) ${ }^{[19]}$, Kai Daxue (2014) ${ }^{[20]}$, Li Mei et al. (2012) ${ }^{[21]}$, Han Xianfeng et al. (2018) ${ }^{[22]}$ found that the reverse technology spillover effect of outward foreign direct investment can be significant only after reaching a certain threshold level.

To sum up, there are more positive effects of technology spillovers on technology spillovers in China and abroad. The research on the impact of manufacturing industry, especially the equipment manufacturing industry; but on technological progress, is still relatively small. Reverse technology spillover in outward foreign direct investment is an important factor affecting the development of China's equipment manufacturing industry and promoting the efficiency of technological progress. Therefore, for China's equipment manufacturing industry, the impact of outward foreign direct investment on its technological progress remains to be further studied and analyzed.

\section{THE INFLUENCE MECHANISM OF OUTWARD FOREIGN DIRECT INVESTMENT ON TECHNOLOGICAL PROGRESS}

A country, an industry or an enterprise wants to obtain and maintain the international competitive advantage under the background of economic globalization and the rapid development of modern science and technology, the speed and performance of its technology R\&D upgrading play an increasingly important role. Under the global open economic system, it is often difficult for the backward countries to catch up with the pace of technological progress only by relying on their own knowledge accumulation and technological research and development. They must rely on both domestic and foreign aspects. At present, compared with developed countries, China's overall investment in science and technology research and development is insufficient, and the level of technological innovation is still relatively low. All of these need to make 
Nov-Dec 2020 / Available online: https://ijels.com/

use of outward foreign investment channels, learn from the science and technology of those advanced countries and regions, enhance their own R\&D capabilities, and improve the level of science and technology. The main paths and modes of international technology diffusion are international trade and capital flow (foreign direct investment and outward foreign direct investment). In order to maintain the monopoly advantage, multinational corporations often take various measures to protect their advanced technologies, especially some core technologies. It is difficult for China to obtain the benefits of technology diffusion in attracting foreign direct investment or in some traditional trade and economic exchanges, and some reasonable technology transfer will also be subject to various difficulties and obstacles. Through the way of outward foreign direct investment, China can bypass the restrictive barriers of international trade and outward foreign direct investment, invest in advanced technology countries and technology distribution centers, set up research and development centers, enter foreign markets in the form of mergers and acquisitions, joint ventures or alliances, make full use of international market elements, and seek various advanced technologies through various channels to promote China's technological progress.

This paper integrates the previous research results, integrates and expands the existing analysis framework, and analyzes the mechanism of the impact of OFDI on technological progress from the perspective of enterprise to industry.

\subsection{Enterprise level transmission mechanism}

In order to adapt to the new situation of economic globalization and based on the new situation of international division of labor and the development of global foreign investment, according to their comparative advantages, multinational enterprises in most countries will reasonably arrange every link of production process in their host countries which have advantages in technology, labor force or natural resources, so as to implement specialized and large-scale production and realize the maximization of resource allocation and profit. However, in order to maintain the technological monopoly advantage, developed countries with advanced technology often take various measures to prevent the diffusion of their own advanced technology, and arrange their core technology and core production links in the domestic hightech production research and development base. Therefore, technology spillover and diffusion in developed countries and regions are still important sources for developing countries to acquire advanced technologies. At present, the investment of multinational enterprises in developed countries is mainly technology seeking investment, which is an important investment way to obtain advanced technology, mainly including foreign new investment and cross-border merger and acquisition investment.

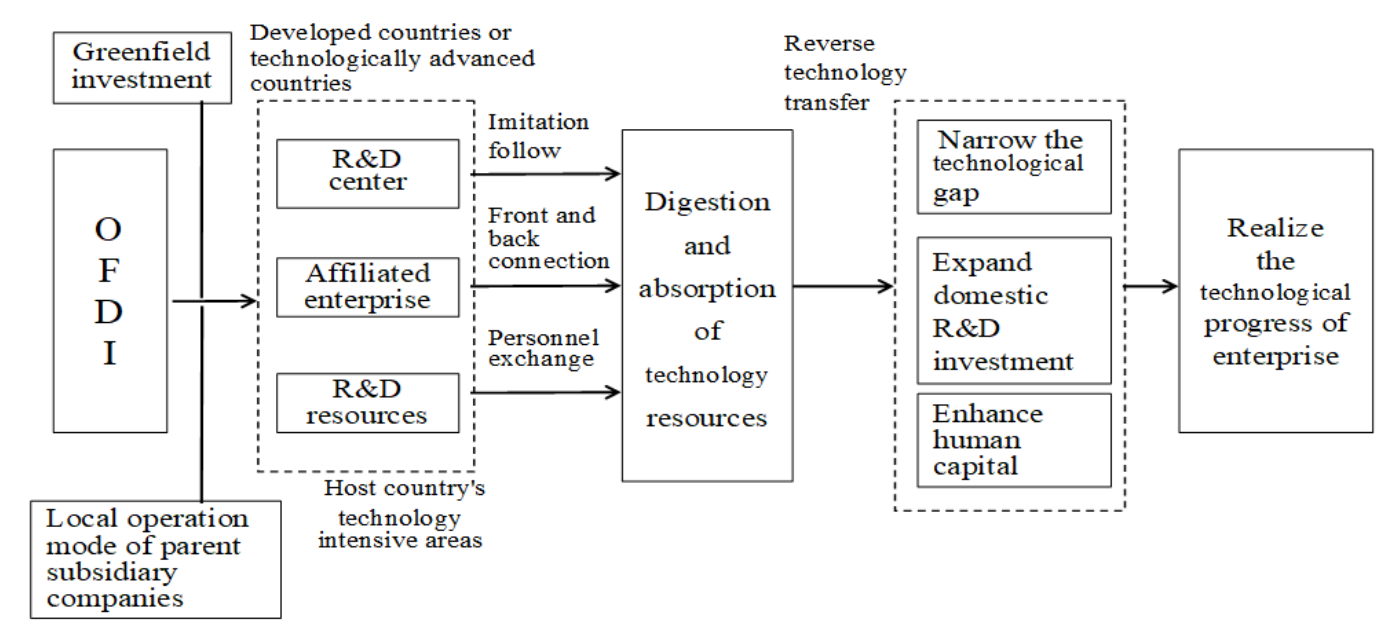

Fig.1: The transfer mechanism of reverse technology spillover effect of new investment

\subsubsection{Transfer mechanism of reverse technology spillover effect of new investment}

Greenfield investment, also known as new investment, is a kind of outward foreign direct investment in which multinational enterprises have the right of operation and management control over their newly-built enterprises in the host country. In recent years, under the guidance of the trend of economic globalization and the profound impact of the international financial crisis, Chinese enterprises have accelerated the pace of outward foreign direct investment and transnational operation. Figure 1 shows the transfer mechanism of reverse technology spillover effect of new investment. Under the circumstances that domestic 
enterprises enter developed countries or technologically advanced countries and host country's technology intensive areas by adopting green space investment and local operation mode of parent subsidiary companies, the transfer mechanism of reverse technology spillover effect of new investment includes three stages: technology interaction and acquisition, digestion and absorption of technology resources, and reverse technology transfer. And three paths of imitation follow, front and back connection, personnel exchange, etc., are carried out in turn and pushed forward layer by layer to realize the technological progress of enterprises.

In the stage of technology interaction and technology acquisition, multinational enterprises have geographical advantages in carrying out outward foreign investment in developed countries or host countries with high technology resources. It has the advantages of technology interaction and technology acquisition with local R\&D centers, all kinds of affiliated enterprises and rich R\&D resources. So it can better integrate into the local science and technology development circle, and can better discover and learn their advanced technology. Through various R\&D institutions and information exchange platforms of the host country, it can carry out knowledge interaction activities among enterprises and acquire the knowledge of the host country cutting edge technical information, as well as various $\mathrm{R} \& \mathrm{D}$ technology resources. In the stage of assimilation and absorption of technological resources, on the one hand, multinational enterprises sort out and screen all kinds of R\&D technology information obtained from abroad through various forms, such as expert consultation meeting, study seminar and training meeting, experience exchange meeting, etc.; on the other hand, they organize internal R\&D personnel to develop relatively advanced technologies in the industry on the basis of the existing advanced technology in the host country according to their own R\&D capabilities and technological development status. In the stage of transnational transfer of reverse technology, new companies or foreign subsidiaries acquire and absorb technological resources from abroad. After the reverse technology is transferred to China, it can narrow the technological gap of enterprises, expand domestic R\&D investment, enhance human capital, and promote the technological progress of enterprises.

In fact, from the three stages of technology access, interaction and acquisition, to the digestion and absorption of technological resources, and then to the reverse technology spillover transfer, the implementation path of multinational enterprises has three paths: imitation follow effect, front and back connection effect and personnel exchange effect.
The first path is imitation following effect, which is the basic effect of reverse technology spillover in OFDI. Multinational enterprises can make use of the geographical advantages of the host country with advanced investment technology, imitate and learn the advanced production technology, technology patents and other scientific research achievements of the host country, follow and grasp the cutting-edge trends of scientific and technological development, and then carry out secondary scientific and technological development in combination with the technical requirements of the home country's products, so as to promote the technical integration and upgrading, and promote the rapid improvement of the parent company's technological progress.

The second path is the front and back connection effect. When a country's enterprises invest in the host country to set up factories, there is no doubt that they will have economic and trade cooperation with the local enterprises. As a link of the relevant industrial chain of the host country, it is interrelated with the front and back industries, thus it is integrated with the local product $R \& D$ center and scientific research network system. In this way, multinational enterprises can make full use of various $R \& D$ elements in the industrial chain to improve the $R \& D$ capability and scientific research level of the parent company.

The third path is the effect of personnel exchange. High level of human capital is an important symbol of technological progress of a country's enterprises and industries. Multinational enterprises invest in the technology-leading host countries and obtain technical resources with the exchange of technical personnel, which is an important carrier of technology flow. On the one hand, because of the externality of technology, it is easy for multinational enterprises to recruit high-level scientific and technological personnel, technical workers and management personnel. These personnel often have local advanced technical knowledge and management experience, which can provide technical support for enterprises to open up the international market, and also provide favorable conditions for the home country to obtain advanced technology. On the one hand, multinational enterprises can also send their parent company's professional and technical personnel to foreign subsidiaries for further study. They can not only cooperate with local R\&D institutions and training institutions, but also exchange and learn with high-level technical personnel in overseas subsidiaries. In this way, the advanced personnel will integrate the tacit knowledge they have learned, internalize the feedback to the technology platform of the home country, carry out bold development 
and innovation, and maximize the technical level of the enterprises in the home country.

\subsubsection{Transfer mechanism of reverse technology} spillover effect of cross-border M\&A (joint venture)

Cross border M\&A is a kind of outward foreign direct investment behavior through the acquisition, sole proprietorship, joint venture or alliance investment to purchase all the assets or shares (rights) that can control the operation and management activities of the merged enterprise. At present, cross-border M\&A is the most important investment mode in the industry characterized by high-tech. By acquiring and integrating technological innovation resources, multinational enterprises can quickly acquire high and new technology, improve the level of technological progress and enhance international competitiveness. Figure 2 shows the transfer mechanism of reverse technology spillover effect of cross-border M\&A (joint venture).

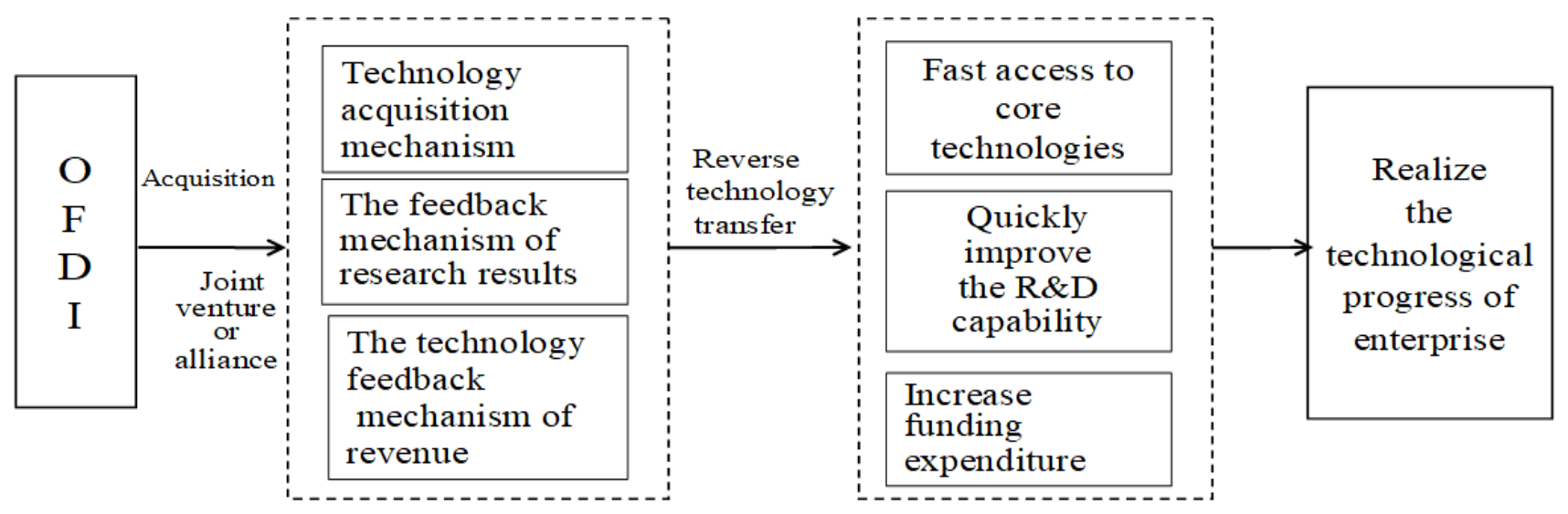

Fig.2: The transfer mechanism of reverse technology spillover effect of cross-border M\&A (joint venture)

First, technology acquisition mechanism. Compared with Greenland investment, cross-border M\&A can enable multinational enterprises to quickly obtain the technological resources of the merged enterprises, such as product production process, patent brand, $R \& D$ information, etc. At the same time, they can also share the internal R\&D platform and external R\&D network system of the merged enterprises, so as to quickly obtain information resources such as new technologies of products or new trends of industrial development, so as to improve rapidly the parent company's R\&D capability enhances its international competitiveness.

Second, the feedback mechanism of research results. Multinational enterprises in technologically advanced host countries conduct secondary technology development on the basis of foreign R\&D by acquiring the R\&D centers of local enterprises, and feed the research results back to the home enterprises. These technological achievements can be learned and absorbed by the home country enterprises, which can quickly improve the R\&D capability and promote the technological progress of enterprises.

Third, the technology feedback mechanism of revenue. This is equivalent to the income compensation mechanism of technology seeking foreign investment. Multinational enterprises have acquired foreign enterprises and acquired advanced production technology. The parent company uses the acquired production technology for product R\&D and scale production, reduces production costs, increases sales revenue, and improves profit margin, which is equivalent to increasing wealth. Multinational enterprises use part of this wealth for technology research and development, which can increase funding expenditure, increase $R \& D$ investment, increase enterprise independent R\&D efforts, and improve the level of technological progress of enterprises.

3.1.3 Forward OFDI mechanism to promote technology progress of home country enterprises

From the previous research, the transfer mechanism of reverse technology spillover effect of new investment and cross-border M\&A (joint venture) mainly reflects the process of reverse technology spillover of foreign direct investment to developed countries. Different from the purpose of investing in developed economies, China's outward foreign direct investment (OFDI) in Southeast Asia, Latin America and other developing countries has less investment target in technology seeking, but mainly market seeking investment. The purpose is to expand overseas markets, gain profits through expanding market 
Nov-Dec 2020 / Available online: https://ijels.com/

scales and reduce $\mathrm{R} \& \mathrm{D}$ costs. At present, it is an era relying on knowledge and cooperation. It is difficult for a single country or enterprise to invest a huge amount of human and material resources for research and development at a high cost. The cost of $R \& D$ needs to be shared in order to achieve scale economy. When China invests in developing countries, it can gain scale benefit, which is equivalent to increasing $R \& D$ investment and sharing research costs. Figure 3 shows the mechanism of forward OFDI to promote the technological progress of home country enterprises, including two aspects: one is that Chinese enterprises invest in these developing countries, take advantage of their own technological advantages, use local materials, produce and sell on the spot, and multinational enterprises return the profits obtained from overseas production and operation to their home countries. The income of the home company will increase, thus further increasing the parent company's R\&D investment and realizing the enterprise's technological progress. Second, the market of developing countries is vast. The expansion of investment scale of multinational enterprises can further promote the export of domestic upstream and downstream products, which helps to play the scale effect, and correspondingly reduce the average cost of unit product and the apportioned $R \& D$ cost, thus reducing the $R \& D$ cost of unit product, which is equivalent to increasing the $R \& D$ investment of home companies and promoting the technological progress of enterprises.

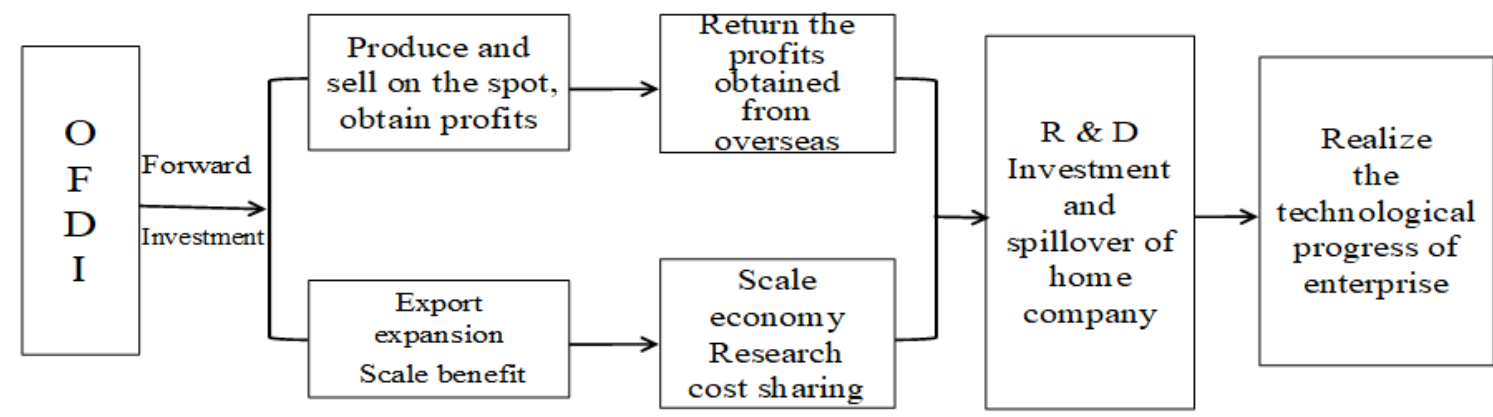

Fig.3: The mechanism of forward OFDI to promote the technological progress of home country enterprise

\subsection{Industrial transmission mechanism}

In order to further analyze the impact of reverse technology spillover of outward foreign direct investment on technological progress, it is expanded from the enterprise level to the industrial level. From the industrial level, due to the externality of technology spillover, multinational enterprises obtain advanced technology resources through the reverse technology spillover channel of outward foreign direct investment. After domestic technology diffusion, other domestic enterprises also enjoy the "technology dividend", and the "technology dividend" is extended to related industries, thus promoting the technological progress of related industries. Figure 4 shows that the transmission mechanism of reverse technology spillover of outward foreign direct investment to industrial technological progress mainly includes five aspects: first, multinational enterprises set up R\&D centers in wholly foreign-owned enterprises, mergers and acquisitions or alliances, strengthen technological research and development, implement technological upgrading and specialized production, so as to optimize the production structure, enhance the international competitiveness of the home country's industries, and then promote industrial technological progress. Second, through foreign investment, linkage upstream and downstream, multinational enterprises reduce the price of export products, improve the productivity of domestic suppliers, expand the industrial scale, form a strong scale economy effect, and promote industrial technology progress. Third, multinational enterprises obtain advanced technology from foreign direct investment, promote technological innovation of home country, enhance industry competitiveness, obtain technical income, and improve residents' income level, so as to stimulate consumption and expand investment, and promote technological progress of home country industry. Fourth, multinational enterprises can directly or indirectly obtain high-quality human resources of host countries through foreign direct investment in technologically advanced host countries, which is equivalent to increasing domestic human capital, thus improving the quality of industrial workers and promoting industrial technological progress. Fifthly, through technology spillover effect, international technology diffusion and transfer between industries, and technology spillover within industries, we can learn from each other, digesting and absorbing so as to promote the overall technical level of the industry and achieve industrial technological progress. 


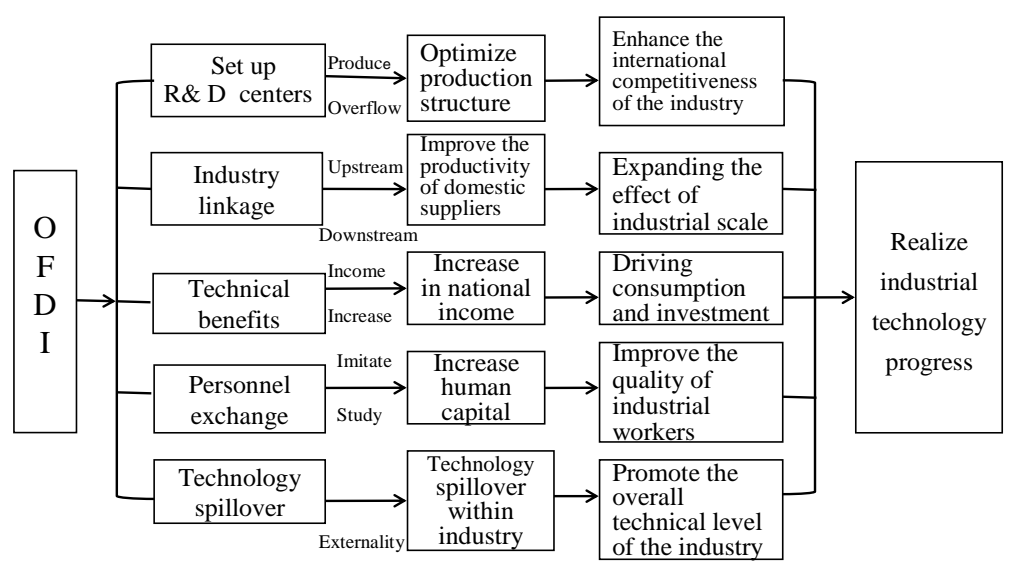

Fig.4: The transmission mechanism of reverse technology spillover of OFDI to industrial technological progress

\section{RESEARCH DESIGN AND VARIABLE SELECTION}

Due to the particularity of Tibet and the lack of economic data, this paper does not include Tibet Autonomous Region in the empirical analysis. Taking 30 provinces in China as the research objects, this paper selects the panel data of various industries and OFDI of equipment manufacturing industry from 2003 to 2017 as samples, and makes an empirical analysis on the effect of OFDI at provincial level on the technological progress of equipment manufacturing industry in each province.

\subsection{Variable selection and data source}

\subsubsection{Explained variables}

The explained variable is TFPCH of equipment manufacturing industry. Many experts have studied the technology spillover under the condition of open technology spillover. Any technological progress will ultimately depend on the change of TFP (Zhao Wei et al., 2006). At present, most researchers regard TFP as the representative variable of technological progress, and the existing research results are measured by TFP (Fu Lei et al., 2013). According to the hypothesis of this paper, the effect of technological progress is reflected in the continuous improvement of technical level and total factor productivity of equipment manufacturing industry, so this index is used to measure the effect of technological progress.

On the measurement of TFPCH, many experts and scholars generally use DEA-Malmquist productivity index to measure TFPCH. This method defines Malmquist productivity index based on distance function, and uses linear optimization method to estimate the boundary production function of each decision-making unit, so as to measure the technological progress and efficiency improvement. Under the first mock exam, the Malmquist index is the total factor productivity change. As the DEAMalmquist index analysis method is simple and applicable, and the results are objective, this paper measures the total factor productivity change index of equipment manufacturing industry. The total industrial output value of the equipment manufacturing industry (after 2012, since the total industrial output value is no longer published in the relevant statistical yearbooks, it is replaced by the main business income index) is the output index; the labor input index is shown by the annual average number of employees in the manufacturing industry; the capital investment index is replaced by the annual net fixed assets of the equipment manufacturing industry. The relevant data are from China Industrial Economic Yearbook, China Industrial Yearbook and China Statistical Yearbook. The total industrial output value (main business income), net fixed assets and employees of equipment manufacturing industry of all provinces in 2003-2017 are selected. Taking 2003 as the constant price, the ex-factory price index of industrial producers and the investment price index of fixed assets are used respectively. This paper uses DEAP2.1 software to measure the TFPCH of equipment manufacturing industry. The results are shown in Table 1. 
Table 1 Average value of Malmquist productivity change index in 2003-2017

\begin{tabular}{|c|c|c|c|c|c|c|c|}
\hline Province & $\begin{array}{l}\text { Index } \\
\text { mean }\end{array}$ & Province & $\begin{array}{l}\text { Index } \\
\text { mean }\end{array}$ & Province & $\begin{array}{l}\text { Index } \\
\text { mean }\end{array}$ & Province & $\begin{array}{l}\text { Index } \\
\text { mean }\end{array}$ \\
\hline Beijing & 1.048 & Shanghai & 1.067 & Hubei & 1.069 & Yunnan & 1.088 \\
\hline Tianjin & 1.055 & Jiangsu & 1.068 & Hunan & 1.103 & Shanxi & 1.1 \\
\hline Hebei & 1.071 & Zhejiang & 1.059 & Guangdong & 1.033 & Gansu & 1.134 \\
\hline Shanxi & 1.1 & Anhui & 1.092 & Guangxi & 1.084 & Qinghai & 1.093 \\
\hline $\begin{array}{c}\text { Inner } \\
\text { Mongolia }\end{array}$ & 1.088 & Fujian & 1.059 & Hainan & 0.986 & Ningxia & 1.135 \\
\hline Liaoning & 1.045 & Jiangxi & 1.124 & Chongqing & 1.066 & Xinjiang & 1.15 \\
\hline Jilin & 1.048 & Shandong & 1.079 & Sichuan & 1.073 & & \\
\hline Heilongjiang & 1.059 & Henan & 1.083 & Guizhou & 1.11 & Total & 1.086 \\
\hline
\end{tabular}

\subsubsection{Explanatory variables}

Outward foreign direct investment (OFDI) is used as the explanatory variable. The stock data of foreign direct investment of each province in each year is selected, which is derived from the Statistical Bulletin of China's Outward Foreign Direct Investment.

\subsubsection{Control variables}

4.1.3.1 Per capita GDP (PCGDP): the improvement of total factor productivity is closely related to economic growth. Macroeconomic development has a significant impact on the change of productivity. Per capita GDP is the main indicator reflecting the level of local economic and social development. The data is from China Statistical Yearbook.

4.1.3.2 R\&D expenditure (RD): investment in science and technology is an important means to promote technological progress. Increasing expenditure on scientific research activities and improving scientific research capacity is conducive to accelerating technological innovation, enhancing technology spillover effect and promoting productivity of equipment manufacturing enterprises. In this paper, the total $R \& D$ expenditure of Industrial Enterprises above Designated Size (large and medium-sized industries) is selected as the index data to measure the investment in science and technology, which is derived from the annual China Science and Technology Statistical Yearbook.

4.1.3.3 Number of invention patents (NIP): the number of invention patents owned by industrial enterprises above scale (large and medium-sized industries) is selected to reflect the level of local scientific research. The data is from China Science and Technology Statistical Yearbook.

The descriptive statistics of variables are shown in Table 2.

Table 2 Descriptive statistics of main variables

\begin{tabular}{cccccc}
\hline Variable & Observations & Mean value & Standard deviation & Minimum & Maximum \\
\hline TEPCH & 420 & 1.086 & 0.128 & 0.628 & 1.659 \\
OFDI & 420 & 292.2 & 823.1 & 0.0800 & 9663 \\
PCGDP & 420 & 18183 & 9749 & 3808 & 55307 \\
RD & 420 & 231.0 & 376.1 & 1.720 & 3525 \\
NIP & 419 & 9492 & 25397 & 7 & 289238 \\
\hline
\end{tabular}

\section{EMPIRICAL PROCESS AND RESULT ANALYSIS}

Based on the literature of experts and scholars, this paper establishes the following basic regression model:

ISSN : 2456-7620
$\mathrm{TFPCH}_{\mathrm{it}}=\alpha+\beta_{1} \mathrm{OFDI}_{\mathrm{it}}+\beta_{2} \mathrm{PCGDP}_{\mathrm{it}}+\beta_{3} \mathrm{RD}_{\mathrm{it}}+\beta_{4} \mathrm{NIP}_{\mathrm{it}}+\varepsilon_{\mathrm{it}}$

$\mathrm{TFPCH}_{\mathrm{it}}$ is the index of the change of total factor productivity in the equipment manufacturing industry in the province i compared with the previous period $\mathrm{T}-1$. 
$\mathrm{OFDI}_{\mathrm{it}}$ is the total foreign direct investment of the province $\mathrm{i}$ in phase $\mathrm{T}$. In order to eliminate the influence of exchange rate and price factors, all the values of OFDI in this paper are converted into RMB price with the official exchange rate, and adjusted with fixed assets investment price index. PCGDP ${ }_{i t}$ is the per capita GDP of the province $i$ in phase $T$, which is flattened by GDP index. $R_{\text {it }}$ is the total R\&D expenditure of the industrial enterprises (large and medium-sized industries) in the province $\mathrm{i}$ in phase $\mathrm{T}$, which is reduced by the consumer price index. NIP it is the patent number of the industry (large and medium-sized industries in individual years) in phase t. $\alpha$ is constant, $\beta 1$, $\beta 2, \beta 3$ and $\beta 4$ are coefficient items, and $\varepsilon_{\text {it }}$ it is random interference.

Considering the economic growth and productivity improvement, it is a dynamic process in the long term, and the change of TFP has some autocorrelation. That is, the productivity development of the last period will affect the productivity of the next period, so the lag period value of the change of TFP is introduced as the explanatory variable. At the same time, the change of technological progress needs a certain time to ferment and brew, so the current period of OFDI will not affect the technological progress rapidly. In the empirical model, the lag period value of OFDI is used as the core explanatory variable. T is the time trend, in order to control the factors of the corresponding variables changing with time. The endogenous problem of the model makes the mixed OLS and the fixed effect estimator biased. Therefore, this paper uses the method of GMM to carry on the empirical analysis. The specific empirical model is designed as follows.

$$
\operatorname{lnTFPCH} \mathrm{it}_{\mathrm{it}}=\alpha+\beta_{0} \operatorname{lnTFPCH} \mathrm{H}_{\mathrm{it}-1}+\beta_{1} \operatorname{lnOFDI} \mathrm{I}_{\mathrm{it}-1}+\beta_{2}
$$$$
\operatorname{lnPCGDP} \mathrm{it}_{\mathrm{it}}+\beta_{3} \operatorname{lnRD_{\mathrm {it}}}+\beta_{4} \ln \operatorname{NIP}_{\mathrm{it}}+\mathrm{t}+\varepsilon_{\mathrm{it}}
$$

Analyze the results in column (6) of Table 3. The coefficient of L_lnOFDI is -0.01943, which is significant above $95 \%$ level. This shows that OFDI will significantly reduce the technological progress in the province. Since the explanatory variables and explanatory variables are treated with logarithm, the coefficient here means the elasticity coefficient of total factor productivity's outward direct investment, that is, the degree of technological progress changes caused by the change of foreign direct investment. -0.01943 shows that every $1 \%$ increase in the amount of foreign investment, technological progress will be reduced by $1.9 \%$.

Table 3 Regression results of the model

\begin{tabular}{|c|c|c|c|c|c|c|}
\hline & \multicolumn{3}{|c|}{ Fixed effect } & \multicolumn{3}{|c|}{ System GMM } \\
\hline & (1) & (2) & (3) & (4) & (5) & (6) \\
\hline & $\operatorname{lnTEPCH}$ & $\operatorname{lnTEPCH}$ & lnTEPCH & $\operatorname{lnTEPCH}$ & lnTEPCH & lnTEPCH \\
\hline \multirow[t]{2}{*}{ L.InTEPCH } & & & & $-0.06261^{* * *}$ & $-0.06842^{* *}$ & $-0.05103^{*}$ \\
\hline & & & & $(0.000)$ & $(0.001)$ & $(0.040)$ \\
\hline \multirow[t]{2}{*}{ L_lnOFDI } & $-0.03044^{* * *}$ & -0.02025 & -0.01616 & $-0.04453^{* * *}$ & $-0.02409^{* * * *}$ & $-0.01943^{* * *}$ \\
\hline & $(0.000)$ & $(0.070)$ & $(0.181)$ & $(0.000)$ & $(0.000)$ & $(0.000)$ \\
\hline \multirow[t]{2}{*}{ lnPCGDP } & & -0.05723 & -0.02450 & & $0.08587^{*}$ & 0.01418 \\
\hline & & $(0.264)$ & $(0.648)$ & & $(0.038)$ & $(0.432)$ \\
\hline \multirow[t]{2}{*}{$\ln R D$} & & $-0.02163^{*}$ & 0.03188 & & -0.00498 & $-0.00730^{*}$ \\
\hline & & $(0.036)$ & $(0.246)$ & & $(0.257)$ & $(0.044)$ \\
\hline \multirow[t]{3}{*}{$\operatorname{lnNIP}$} & & -0.00511 & $0.05394^{* *}$ & & $-0.04094^{* * *}$ & $-0.03274^{* * *}$ \\
\hline & & $(0.684)$ & $(0.001)$ & & $(0.000)$ & $(0.000)$ \\
\hline & & & Time effect & & & \\
\hline \multirow[t]{2}{*}{ year } & & & & & & 0.00118 \\
\hline & & & & & & $(0.593)$ \\
\hline \multirow[t]{2}{*}{ _cons } & $0.18271^{* * *}$ & 0.84136 & -0.15204 & $0.24448^{* * * *}$ & -0.32628 & -2.07646 \\
\hline & $(0.000)$ & $(0.087)$ & $(0.765)$ & $(0.000)$ & $(0.389)$ & $(0.640)$ \\
\hline$N$ & 390 & 389 & 389 & 390 & 389 & 389 \\
\hline
\end{tabular}


Nov-Dec 2020 / Available online: https://ijels.com/

\begin{tabular}{l|ccc|cccc}
$R^{2}$ & 0.167 & 0.181 & 0.355 & $\operatorname{AR}(2)$ & 0.19 & 0.34 & 0.338 \\
$\mathrm{~F}$ & 71.77666 & 19.62610 & 11.79516 & Sargan & 0.99 & 0.99 & 0.99 \\
\hline
\end{tabular}

Considering that there may be reverse technology spillover effect in OFDI, we add the square term of OFDI lagged for one period to carry out GMM dynamic panel regression. The results are shown in column (3) of Table 4. The coefficient of SQ_LlnOFDI is 0.00526 , and the sign is positive, that is to say, it presents a significant positive $U$ shape. It can be seen that there is a threshold for the impact of OFDI on domestic technological progress. Before reaching the threshold, OFDI will reduce the technological progress of provinces carrying out foreign investment, but with the increasing scale of OFDI, it will promote domestic technological progress. This shows that the international technology exchange and cooperation and technological innovation will appear only after the outward foreign direct investment reaches a certain scale, and the reverse technology spillover effect will begin to appear. The threshold $\operatorname{lnOFDI}=(-(-0.05801) /(2 *$ $0.00526)=5.514)$, OFDI $=24.8$ billion yuan. That is, from the historical data, when the average level of outward foreign direct investment reaches more than 24.8 billion yuan, the technological progress effect will arise. The possible reason is that after reaching a certain scale, the technological R\&D exchanges and cooperation between the two places can reach a certain depth.

According to the model analysis of the average stock of China's outward direct investment after exchange rate conversion and price index adjustment (see Table 5), from the national level, the average OFDI in 2008 was 28.196 billion yuan, which exceeded the threshold of 24.8 billion yuan, indicating that 2008 was a turning point. Since then, the role of China's outward foreign direct investment in promoting the technological progress of equipment manufacturing industry began to show gradually, which is also in line with the global financial crisis in 2008. The price of international assets decreased significantly, which provided a good opportunity for Chinese enterprises to carry out cross-border mergers and acquisitions and promote the reverse technology spillover of outward foreign direct investment. It also shows that under the background of the international financial crisis at that time, China's outward foreign direct investment increased rapidly instead of slowing down.

Table 4 Regression results of the model

\begin{tabular}{cccc}
\hline & $(1)$ & $(2)$ & $(3)$ \\
& $\ln$ TEPCH & $\operatorname{lnTEPCH}$ & $\operatorname{lnTEPCH}$ \\
\hline L.InTEPCH & $-0.06842^{* *}$ & $-0.05346^{* * *}$ & $-0.08188^{* * *}$ \\
& $(0.001)$ & $(0.000)$ & $(0.000)$ \\
L_lnOFDI & $-0.02409^{* * *}$ & $-0.0534^{* * *}$ & $\mathbf{- 0 . 0 5 8 0 1 * * *}$ \\
& $(0.000)$ & $(0.000)$ & $(0.000)$ \\
SQ_LlnOFDI & & $0.00399^{* * *}$ & $\mathbf{0 . 0 0 5 2 6 * * *}$ \\
& & $(0.000)$ & $(0.000)$ \\
lnPCGDP & $0.08587^{*}$ & $0.06269^{*}$ & $0.12739^{* *}$ \\
& $(0.038)$ & $(0.031)$ & $(0.007)$ \\
InRD & -0.00498 & $-0.01166^{* *}$ & $-0.01348^{* * *}$ \\
& $(0.257)$ & $(0.009)$ & $(0.000)$ \\
lnNIP & $-0.04094^{* * *}$ & $-0.03100^{* * *}$ & $-0.03814^{* * *}$ \\
& $(0.000)$ & $(0.000)$ & $(0.000)$ \\
year & & & -0.00129 \\
& & & $(0.794)$ \\
_cons & -0.32628 & -0.10915 & 1.92727 \\
& $(0.389)$ & $(0.669)$ & $(0.847)$ \\
\hline
\end{tabular}




\begin{tabular}{|c|c|c|c|}
\hline$N$ & 389 & 389 & 389 \\
\hline \multicolumn{4}{|l|}{$R^{2}$} \\
\hline $\mathrm{F}$ & & & \\
\hline
\end{tabular}

Table 5 Average value of China's OFDI stock (Unit: 100 million yuan)

\begin{tabular}{cccccc}
\hline Region & China & $\begin{array}{l}\text { Eastern } \\
\text { Region }\end{array}$ & $\begin{array}{c}\text { Central } \\
\text { region }\end{array}$ & $\begin{array}{c}\text { Western } \\
\text { Region }\end{array}$ & $\begin{array}{c}\text { Northeast } \\
\text { China }\end{array}$ \\
\hline 2004 & 119.6 & 47.64 & 2.21 & 1.88 & 7.58 \\
2005 & 148.65 & 64.19 & 5.01 & 3.17 & 13.11 \\
2006 & 186.83 & 85.87 & 6.92 & 4.84 & 25.46 \\
2007 & 231.13 & 123.17 & 12.28 & 10.18 & 32.36 \\
2008 & $\mathbf{2 8 1 . 9 6}$ & 123.2 & 15.2 & 15.21 & 39.14 \\
2009 & 386.61 & $\mathbf{1 6 8 . 8 5}$ & 36.63 & 22.37 & 65.24 \\
2010 & 484.29 & 239.98 & 53.18 & 34.58 & 106.73 \\
2011 & 590.71 & 304.09 & 68.62 & 45.41 & 122.98 \\
2012 & 697.14 & 427.39 & 92.4 & 68.51 & $\mathbf{1 8 0 . 9 1}$ \\
2013 & 850.8 & 570.43 & 119.4 & 82.66 & 213.89 \\
2014 & 1152.07 & 846.25 & 146.06 & 105.28 & 251.02 \\
2015 & 1500.45 & 1328 & $\mathbf{2 1 4 . 2 8}$ & 140.48 & 308.5 \\
2016 & 2023.62 & 2250.27 & 315.42 & $\mathbf{2 0 5 . 0 2}$ & 395.99 \\
2017 & 2639.04 & 3114.66 & 352.7 & 243.56 & 361.77 \\
\hline
\end{tabular}

Source: Statistics Bulletin of China's Outward Foreign Direct Investment , constant price in 2004 , adjusted by fixed asset price index.

In order to further explore the difference of OFDI on $\mathrm{TFPCH}$ in different regions, in this paper, three dummy variables are set up, namely, the East, the Middle and the West, and the Northeast is taken as the comparison object. Among them, OFDI_E is the cross-multiplication term between OFDI and Eastern dummy variable; OFDI_M is the intersection term between OFDI and central China, OFDI_W is the intersection term between OFDI and the western region. Column (4) in Table 6 below is the final result after controlling other control variables. It can be seen that under the control of regional variables, the impact of OFDI lagged on technological progress still presents a significant positive U-shape. And, combined with the coefficient of OFDI_E (East), OFDI_M (middle), OFDI_W (West), the threshold of lnOFDI in the East $=(-$ $(-0.06601-0.0000) /(2 * 0.00656))=5.03$, OFDI $=153$; the threshold of lnOFDI in the middle $=(-(-0.06601+$ $0.00043) /(2 * 0.00656))=4.998$, OFDI $=148$ in the East; the threshold of lnOFDI in the West $=(-(-0.06601+$ $0.00011) /(2 * 0.00656))=5.02$; OFDI $=151.8 ;$ the threshold of lnOFDI in the Northeast $=(-(-0.06601) /(2 *$ $0.00656))=5.03$; OFDI $=152.9$. Taking the $\mathrm{X}-\mathrm{Y}$ axis as the coordinate, the OFDI threshold of the central region is more left, which indicates that the scale of outward foreign investment needed to promote technological progress is relatively small. That is to say, in the case of small outward foreign direct investment, it can play a role in promoting regional technological progress.

From the regional level, according to the average data of outward foreign direct investment stock of each region in Table 5, the average OFDI of eastern region in 2009 was 16.885 billion yuan, exceeding the threshold value of 15.3 billion yuan, indicating that 2009 is a turning point. After 2009, the role of outward foreign direct investment in promoting the technological progress of equipment manufacturing industry in the eastern region began to show gradually. The average OFDI of central China in 2015 was 21.428 billion yuan, which exceeded the threshold value of 14.8 billion yuan, indicating that 2015 was a turning point. After 2015, the role of OFDI in promoting the technological progress of equipment manufacturing industry in Central China began to show gradually. The average OFDI of the western region in 2016 was 20.502 billion yuan, exceeding the threshold of 
Nov-Dec 2020 / Available online: https://ijels.com/

15.18 billion yuan, indicating that 2016 is a turning point. After 2016, the role of outward foreign direct investment in promoting the technological progress of equipment manufacturing industry in the western region gradually began to appear. The average OFDI of Northeast China in 2012 was 18.091 billion yuan, which exceeded the threshold value of 15.29 billion yuan, indicating that 2012 was a turning point. After 2012, the role of OFDI in Northeast China in promoting the technological progress of its equipment manufacturing industry began to show gradually. On the whole, the turning point year that outward foreign direct investment began to play a role in promoting the technological progress of equipment manufacturing industry appeared in various regions. The eastern region was the earliest, followed by the northeast region, and then he central region, and finally the western region. At present, all regions have been in the stage of promoting the technological progress of equipment manufacturing industry by outward foreign direct investment.

Table 6 Regression results of the model

\begin{tabular}{|c|c|c|c|c|}
\hline & (1) & (2) & (3) & (4) \\
\hline & lnTEPCH & $\ln$ TEPCH & $\ln$ TEPCH & $\operatorname{lnTEPCH~}$ \\
\hline \multirow[t]{2}{*}{ L.InTEPCH } & $-0.05103^{*}$ & $-0.06068^{* * *}$ & -0.08189 & $-0.07137^{*}$ \\
\hline & $(0.040)$ & $(0.001)$ & $(0.056)$ & $(0.014)$ \\
\hline \multirow[t]{2}{*}{ L_lnOFDI } & $-0.01943^{* * *}$ & $-0.03149^{* * * *}$ & $-0.04184^{* * *}$ & $-0.06601 * * *$ \\
\hline & $(0.000)$ & $(0.000)$ & $(0.000)$ & $(0.000)$ \\
\hline \multirow[t]{2}{*}{ SQ_LlnOFDI } & & & 0.00193 & $0.00656^{* * * *}$ \\
\hline & & & $(0.250)$ & $(0.000)$ \\
\hline \multirow[t]{2}{*}{ lnPCGDP } & 0.01418 & $0.08639^{*}$ & $0.12303^{* *}$ & $0.13550^{* * *}$ \\
\hline & $(0.432)$ & $(0.022)$ & $(0.002)$ & $(0.001)$ \\
\hline \multirow[t]{2}{*}{$\operatorname{lnRD}$} & $-0.00730^{*}$ & -0.00886 & -0.00667 & $-0.02180^{* * *}$ \\
\hline & $(0.044)$ & $(0.072)$ & $(0.177)$ & $(0.001)$ \\
\hline \multirow[t]{2}{*}{$\operatorname{lnNIP}$} & $-0.03274^{* * *}$ & $-0.04353^{* * *}$ & $-0.04587^{* * *}$ & $-0.02674^{*}$ \\
\hline & $(0.000)$ & $(0.000)$ & $(0.000)$ & $(0.021)$ \\
\hline \multirow[t]{2}{*}{ OFDI_E } & & 0.00001 & 0.00001 & -0.00000 \\
\hline & & (0.109) & $(0.573)$ & $(0.747)$ \\
\hline \multirow[t]{2}{*}{ OFDI_M } & & $0.00035^{* *}$ & $0.00035^{* *}$ & $0.00043^{* *}$ \\
\hline & & $(0.001)$ & $(0.002)$ & $(0.002)$ \\
\hline \multirow[t]{2}{*}{ OFDI_W } & & 0.00012 & 0.00011 & 0.00011 \\
\hline & & $(0.095)$ & $(0.303)$ & $(0.251)$ \\
\hline \multirow[t]{2}{*}{ year } & 0.00118 & & & -0.00804 \\
\hline & $(0.593)$ & & & $(0.145)$ \\
\hline \multirow[t]{2}{*}{ _cons } & -2.07646 & -0.28006 & -0.61666 & 15.36361 \\
\hline & $(0.640)$ & $(0.375)$ & $(0.095)$ & $(0.165)$ \\
\hline$N$ & 389 & 389 & 389 & 389 \\
\hline \multicolumn{5}{|l|}{$R^{2}$} \\
\hline $\mathrm{F}$ & & & & \\
\hline
\end{tabular}

\section{CONCLUSION AND SUGGESTIONS}

Based on the panel data of 30 provinces in China from 2003 to 2017, through the construction of input-output index system, this paper uses DEA-Malmquist analysis model to measure the change of total factor productivity of equipment manufacturing industry in 30 provinces, and 
further uses the method of Dynamic Panel System GMM to analyze the impact of China's outward foreign direct investment on the total factor productivity change of China's equipment manufacturing industry. The empirical results show that: China's outward foreign direct investment and the technological progress of equipment manufacturing industry present a significant positive " $U$ " shape, that is, at the initial stage of outward foreign investment, the increase of outward foreign direct investment will reduce the technological progress of equipment manufacturing industry, but when the outward foreign direct investment reaches a certain scale and the growth rate of outward foreign direct investment exceeds a certain threshold value, outward foreign direct investment will significantly promote equipment manufacturing technological progress in manufacturing industry. From the national level, after 2008, China's outward foreign direct investment has gradually played an important role in the technological progress of equipment manufacturing industry. From the regional level, after 2009, 2015, 2016 and 2012, the role of outward foreign direct investment in the equipment manufacturing industry of the eastern region began to show.

Based on the above research, in view of the resource seeking type and market seeking type in the initial stage of China's outward foreign direct investment, it began to turn to the technology seeking type. The suggestions are as follows: first, the positive effect of reverse technology of outward foreign direct investment has appeared in China's equipment manufacturing industry. Therefore, we should increase the outward foreign direct investment of manufacturing industry, especially the equipment manufacturing industry, and improve the technical level of China's equipment manufacturing industry through reverse technology spillover, which also reflects the future trend and demand of China's outward foreign direct investment. Second, adjust measures to local conditions and reasonably control the scale of outward foreign direct investment. Equipment manufacturing industry is a technology intensive and capital intensive industry. The development of equipment manufacturing industry cannot do without a large amount of long-term financial support, because OFDI has the "crowding out effect" of capital, especially in the central and western regions, the scale of outward foreign investment should be reasonably controlled. Third, actively encourage cross-border mergers and acquisitions of developed countries. In particular, we should invest in developed countries with advanced technology and emerging industrialized countries and regions, encourage enterprises to carry out cross-border mergers and acquisitions, especially those large enterprises with core technologies, so as to obtain more technology, knowledge and information resources and promote the progress of domestic science and technology. The fourth is to implement different policies of foreign investment among provinces. The eastern developed areas and the northeastern old industrial bases are also important bases of equipment manufacturing industry. Therefore, it is necessary to formulate targeted foreign investment encouragement policies, actively increase technology acquisition oriented foreign investment, speed up the pace of regional enterprises to go global, and improve technological innovation ability. Fifth, increase R\&D investment in China's equipment manufacturing industry, encourage scientific and technological innovation and research related to the equipment manufacturing industry, and the state should give support in terms of taxation and preferential policies for enterprises.

\section{REFERENCES}

[1] Yao Limin, Sun Chunyuan. Empirical analysis of determinants of China's reverse FDI [J]. International trade issues. April 2007

[2] Zhao Wei, Gu Guangdong, He Yuanqing. Outward FDI and China's technological progress: mechanism analysis and tentative practice 〔 $\mathrm{J}]$. Management world, July 2006

[3] KOGUT B, CHANG S. Technological capabilities and Japanese foreign direct investment in the United States $[\mathrm{J}]$ . The Review of Economics and Statistics, 1991, 73(3)

[4] TEECE, DAVID J. Foreign investment and technological development in Silicon $[\mathbf{J}]$. California Management Review, 1992, 34(2).

[5] POTTE R IE B P, LiCHTENBE R G F. Does foreign direct investment transfer technology across borders? [J ] . Review of Economics and Statistics, 2001, 83(3)

[6] PRADHAN J P, SINGH N. Outward FDI and knowledge flows: a study of the Indian automotive sector $[\mathrm{J}]$. International Journal of Institutions and Economies, 2008 , 1(1).

[7] HERZER D. Outward FDI and economic growth [J] . Journal of Economic Studies, 2010, 37(5).

[8] Liu Mingxia. Reverse technology spillover effect of China's Foreign Direct Investment: an analysis based on the impact of technology gap [J]. Journal of Central South University of finance, economics and law, 2010 (3)

[9] Guo Fei, Huang Yajin. Research on the transmission mechanism of OFDI reverse technology spillover effect from the perspective of global value chain: a case study of Huawei Technology Co., Ltd. [J]. Journal of management, $2012,25(3)$ 
[10] Song Yongchao. Research on reverse technology spillover effect of China's Foreign Direct Investment: theoretical model and empirical test [J]. Economic longitude, 2015, 32 (3)

[11] Han Yujun, Wang Li. The impact of OFDI reverse technology spillover on China's energy efficiency $[\mathrm{J}]$. Economic issues, 2016 (3)

[12] BITZER J, GEISHECKER I, GORG H. Productivity spillovers through vertical linkages: evidence from 17 OECD countries $[\mathrm{J}]$. Economics Letters, 2008, 99( 2).

[13] LEE H H, TAN H B. Technology transfer, FDI and economic growth in the ASEAN region $[\mathrm{J}]$. Journal of the Asia Pacific Economy, 2006, 11( 4).

[14] BITZER J , KEREKES M . Does foreign direct investment transfer technology across borders new evidence $[\mathrm{J}]$. Economics letters, 2008, 83(3).

[15] Bai Jie. Reverse technology spillover effect of Foreign Direct Investment: An Empirical Test on China's total factor productivity [J]. World economic research, 2009 (8)

[16] Xie Yumin, Zhou Kaifa, Wei Xiaoping. Research on the reverse spillover effect of foreign direct investment on China's innovation capability $[\mathrm{J}]$. Economic longitude and latitude, 2014 (3)

[17] BORENSZTEIN E, GREGORIO L. How does foreign direct investment affect economic growth? [J] . Journal of International Economics, 1998，45( 1).

[18] GORG H, GREENAWAY D. Much ado about nothing? do domestic firms really benefit from foreign direct investment? $[\mathrm{J}]$. The World Bank Research Observer, 2004, 19( 2).

[19] Chen Yan. An Empirical Study on the reverse technology spillover effect of China's Outward Investment: Based on the perspective of absorptive capacity [J] China soft science, 2011 (10): 61

[20] Kai Daxue. Foreign direct investment, marketization process and technological innovation of domestic enterprises: An Empirical Study Based on panel data of provincial large and medium-sized industrial enterprises [J]. Research and development management, 2014, 26 (5): 14

[21] Li Mei, Liu Shichang. Regional differences and threshold effects of reverse technology spillovers from foreign direct investment: a threshold regression analysis based on China's Provincial Panel Data [J]. Management world, 2012 (1): 21

[22] Han Xianfeng, Hui Ning, Song Wenfei. A new perspective on improving the spillover effect of OFDI reverse Innovation: An Empirical Test Based on environmental regulation [J]. International trade issues, 2018 (4): 103

[23] Fu Yuanhai and others. Foreign direct investment and the transformation of China's economic development mode [M]. Published by Social Science Literature Publishing House , July 2017

[24] Zhang Guosheng. Research on China's foreign direct investment strategy and policy[M]. Published by Economic Science Press , August 2015
[25] Zhang Jifeng. Research on the dynamic mechanism and reverse technology spillover effect of China's foreign direct investment[M]. Northeast University of Finance and Economics Press, September 2015

[26] Feng Yue. Research on the mechanism and effect of FDI on technological progress of China's manufacturing industry[D]. Hehai University, 2007

[27] Liu Xuejiao. Research on GVC pattern, ODI reverse technology spillover and upgrading path of manufacturing industry[D]. University of international business and economics , 2017

[28] Cao Hongtao. Research on the impact of China's foreign direct investment on the development of advanced manufacturing industry[D]. Wuhan University, 2017

[29] Huo Xin. Research on the industrial structure upgrading effect of reverse technology spillover of China's foreign direct investment[D]. Capital University of economics and trade, 2016

[30] Chen Hao. China OFDI and home country industrial upgrading[D]. Zhejiang University, 2018

[31] Zou Xi. Research on the reverse technology spillover effect of China's technology seeking OFDI[D]. Jiangxi University of Finance and economics, 2017

[32] Zhang Hong, Zhao Jiaying. A review on reverse technology spillover effect of Foreign Direct Investment [J]. Economic trends, 2008 (2): 120-125

[33] Cheng Xiaojie. China's Ofdi motivation, technology seeking and Reverse Technology Spillover: a literature review [J]. Graduate Journal of Central South University of Finance and law, may 2012

[34] Gao Wenling. OFDI in China and the impact of technological progress: a literature review [J]. Reform, March 2012

[35] Yu Fei, Yuan Zhitian. Empirical analysis of OFDI's impact on innovation efficiency of China's manufacturing industry under the background of economic globalization [J]. Science and technology and management, July 2018

[36] Guo Juan. Foreign investment and Reverse Technology Spillover: literature review [J]. Hunan Social Sciences, 2013 